\title{
RELIGIJA U DRUŠTVU, O DRUŠTVU, ZA DRUŠTVO ${ }^{1}$
}

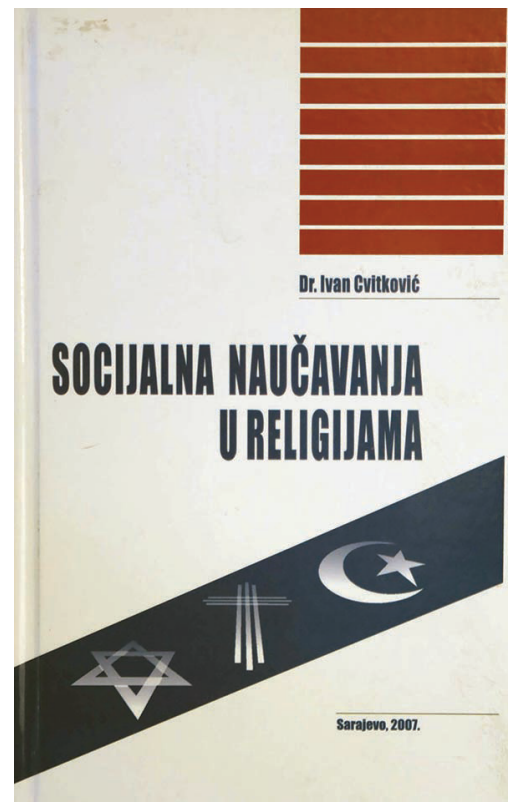

Nova knjiga sarajevskog profesora i sociologa religije Ivana Cvitkovića nam nudi detaljan uvid u društvenu situiranost religije/a, i u njihova poučavanja, odnosno kako autor navodi naučavanja o društvu. Pored sažetog prikaza stajališta brojnih religijskih zajednica o suštinskim društvenim pitanjima, kao što su brak i porodica, moral i odnos prema drugima, problem bogatstva i siromaštva, telesno i duhovno zdravlje, autor nudi i sažet prikaz religijskih stajališta i konkretnih, realnih odnosa prema aktuelnim pitanjima, kao što su fenomen demokratizacije i promocije (pa i ideologizacije) ljudskih prava i ideje civilnog društva. Naravno, naučnik velikog intelektualnog formata kao što je profesor Ivan Cvitković se ne zadržava samo na detaljnom i sažetom opisu religijskih stajališta o najznačajnijim društvenim i zajedničarskim problemima, već svojim kritičkim pristupom ukazuje na brojne protivrečnosti unutar aksioma i dogmi određenih religija, na otklon između proklamovanog i stvarnog te na činjenicu da su brojne društvene protivrečnosti i anomalije bile praćene, a i pravdane, svojim religijskim ekvivalentima. Teoretizaciju društvenih problema u okviru religijskog diskursa autor izvodi iz dubokog poznavanja religijskih izvora i svetih spisa, kao i iscrpne građe o praksi religijskih zajednica u tzv. zemaljskim stvarima kroz istoriju sve do naših dana.

Religijska naučavanja o društvu su bila i ostala u velikoj meri raspeta između svojih univerzalnih vrednosti i partikularne situiranosti koja je uglav-

${ }^{1}$ Prikaz knjige Socijalna naučavanja u religijama. Religija\&tolerancija, god. VI, br. 9, Novi Sad, 2008. 
nom obeležena autoritarnom strukturom i organizacijom. Danas je ta raspetost prevashodno između stajališta koja su u većoj meri pogodna za tradicionalna, zatvorena, patrijarhalna i parohijalna društva i zova modernih vremena za promenom. Tako npr. autor ukazuje na činjenicu da je Katolička crkva vekovima imala ulogu u održavanju društvenih nejednakosti i status quoa, da bi potom prešla u fazu neradog prilagođavanja demokratskim vrednostima, a potom u fazu teološkog pravdanja demokratije, tzv. teologiju oslobođenja (str. 46). Dalje, religije su vekovima cementirale princip rodne nejednakosti, što je danas aktuelan pa i popularan problem s obzirom na polet feminističke misli i implementaciju brojnih standarda čiji je cilj rodna ravnopravnost. U svim pisanim religijskim autoritetima se velika važnost pridaje porodici kao osnovnoj ćeliji društva, velikim delom zbog činjenice da je ona "izvor" novih članova date konfesije (str. 97). Pri tome su žene, uglavnom, imale niži status da bi opskrbile društvo dovoljnim brojem novih članova. Često se dešavalo da se u okviru iste religijske tradicije čuju različita stajališta o ženskom "pitanju". Tako su Jevreji verovali da muškarca može onečistiti pogled na ženu, a sa druge strane žene su vršile pripremu nekih religijskih rituala i podsticale sinove da proučavaju Toru. Novi Zavet daje bolji položaj ženi s obzirom na to da su one pratile Isusa koji se prvo njima ukazao nakon smrti. Međutim, ostaje da su svi apostoli, bar oni zvanični, bili muškarci. U islamskoj tradiciji dužnost žene je pokornost mužu, ona ne sme da izbegava njegovu postelju, da izlazi iz kuće bez njegovog znanja, ne sme da posti ako joj on ne dozvoli i mora biti blagorodna prema njegovim željama.

Jedan od značajnih socijalnih problema kojima su se religijske zajednice bavile je svakako problem siromaštva i društvenih nejednakosti, što je jedan od najznačajnijih društvenih fenomena. U ovom pitanju se možda još jasnije nego u drugim pitanjima vidi sva kompleksnost, pa i protivrečnost u stajalištima religijskih zajednica. Npr., navodi se da je Bog taj koji stvara bogate i siromašne, odn. da je bogatstvo od Boga, a sa druge strane da je ono prolazno, da vodi do zaborava Boga, gordosti, samoljublja. I Biblija i Kur'an često pravdaju društvene nejednakosti, a na nekim mestima osuđuju njegovo gomilanje. Kada je reč o Novom zavetu autor daje zanimljiv podatak da je Marko naklonjeniji bogatašima od Luke (str. 137). Siromaštvo potom može da ljude okrene traženju utočišta u religiji i religijskom zanosu, a s druge strane može da, kao što navodi autor citirajući jedan hadis proroka Muhammeda, vodi do gubitka vere. U svakom slučaju, brojne religijske zajednice značajnu pažnju posvećuju milosrdnim aktivnostima, kako u vreme blagdana tako i u ljudskoj svakodnevnici. Na našim prostorima i šire je razvijena karitativna aktivnost brojnih društava koja su osnovale određene religijske zajednice, npr. Karitas, 
Merhamet, Dobrotvor, La Benevolencija, Adra, i čija je delatnost naročito bila izražena u humanitarnoj pomoći za vreme poslednjih ratova.

Odnosu religija i nasilja je takođe data značajna pažnja, a to je više nego aktuelno s obzirom na ogroman broj sukoba u savremenom svetu koji nose religijski predznak, što smo iskusili i na našim prostorima. Primećuje se da se teško može očekivati da religije razreše društvene konflikte, ali da one svakako mogu doprineti smanjenju nepoverenja i mržnji (str. 285). Autor navodi da su brojne konflikte koji su pratili brojne verske zajednice kroz istoriju vodili ljudi koji su tvrdili da su vernici, a ne same religije kao takve. Monoteističke tradicije su naročito bile sklone nasilju zbog misionarenja i težnje da u svoje okrilje prigrle što veći broj vernika, ne libeći se ni duhovne, a ni fizičke prisile. Ne treba zaboraviti ni da mnogi sukobi imaju samo religijski predznak, a zapravo se vode zbog npr. teritorijalnih i političkih (npr. između Jevreja i Arapa) ili nekih drugih interesa.

Od brojnih problema sa kojima se autor suočava kada je reč o socijalnom nauku i društvenoj praksi brojnih religijskih tradicija, osvrnućemo se još na njihov odnos prema društvenoj demokratizaciji i ljudskim pravima $i$ na problem odnosa prema nacionalnom identitetu, s obzirom na to da se radi o pitanjima koja su značajna u savremenom kontekstu. Gotovo sve religijske zajednice su naglaskom na ispunjavanju verskih obaveza i dužnosti bile sumjičave prema ideji ljudskih prava i uopšte prema demokratiji. Ukazuje se i na to da je teorija o pozitivnoj vezi između protestanata i demokratije problematična, iako je protestantizam u velikoj meri posredno pospešio razvoj demokratije naglaskom na individualizmu, masovnom obrazovanju, zagovaranju razdvojenosti države i crkve i sl. Kada je reč o popularnim tvrdnjama da islam i demokratija ne idu ruku pod ruku, navodi se da se na mnogim mestima u Kur'anu navodi važnost dogovaranja i postojanja razlika u mišljenju, kao i na jaku modernističku struju u okviru islama koja je naklonjena demokratskim vrednostima. U ovom kontekstu treba pomenuti i autorovu primedbu da mnoge demokratske zemlje zbog svojih ekonomskih interesa podržavaju najautoritarnije islamske režime i vode se politikom duplih standarda. U svakom slučaju, zaključuje se da se u eri opšte promocije ljudskih prava ona u enormnim razmerama krše, a na religijama je da svoju verodostojnost potvrde poštujući principe slobode i humanosti (str. 63). Govoreći o odnosu religije/a i nacionalnog identiteta, autor podvlači njegovu aktuelnost s obzirom na tzv. “dreku identiteta" krajem XX i na prelazu u XXI vek. Ovaj problem se možda najjasnije sagledava u okviru jevrejske tradicije, s obzirom na to da je Jahve tvorac čitavog sveta, a Jevreji njegov izabrani narod. Novi zavet teži da prigrli čoveka univerzalno, apstrahovano od njegovog etničke pripadnosti, pri čemu 
je katoličanstvo postalo univerzalno, nadnacionalno, ali ne i anacionalno, poštujući zasebne identitete različitih naroda koji mu pripadaju, dok pravoslavlje teži identifikaciji nacionalne i religijske zajednice. Pri tome se skreće pažnja na to da se pravoslavlje najpre organizovalo na mesnom nivou (što se vidi iz naziva carigradska, aleksandrijska crkva), ali da se kasnije "utelovilo" u okvire nacionalnih država. U protestantizmu i islamu religijska pripadnost pak potpuno prevazilazi vezanost za nacionalne identitete. U svakom slučaju, doktrina se nikada u praksi ne može primeniti u čistom tipu i tu bi se mogla navesti jedna zanimljiva ilustracija autora kada je reč o odnosu konfesionalnog i nacionalnog identiteta. Naime, u Glasu Koncila, br. 43 iz 1990. stoji da "Biti Hrvat znači biti čovek na hrvatski način" i autor se s pravom pita koji je to hrvatski način. "Hadezeovski, sdepeovski, haespeovski, desničarski, ljevičarski, umjerenjački, ustaški, i kakvih sve 'načina' nije prodefiliralo među Hrvatima od 1990. do 2007" (str. 79).

Iz ovog kratkog prikaza i osvrta svakako sledi i topla preporuka da svako ko želi da se bavi sociologijom, a naročito sociologijom religije, kao pozivom treba da se upozna sa radom profesora Cvitkovića u ovoj oblasti. Knjiga Socijalna naučavanja u religijama može takođe biti korisna studentima budući da na iscrpan, ali sažet i sistematičan način daje odnos dogmi, vrednosti, normi i praksi različitih religija prema različitim društvenim pitanjima i problemima. Knjiga pri tome ne daje samo odgovore na stara već i pokreće mnoga nova pitanja i probleme, a daje i inspirativan okvir načina na koji se njima treba baviti. Pri tome je posebno značajno autorovo upozorenje koje provejava iz teksta da, iako religije pretenduju da svoj legitimitet crpe iz onostranog, nadnaravnog autoriteta, to ih ne oslobađa društvene odgovornosti u ovom svetu. Naročito s obzirom na njihovu pretenziju da budu arbitar u brojnim pitanjima: od pitanja individualnog i ličnog razvoja, preko definisanja poželjnih odnosa u porodici i neposrednoj zajednici, pa sve do pitanja od šireg, javnog, društvenog značaja i kod nas popularnog "nacionalnog interesa". Ovo poslednje je naročito karakteristično s obzirom na to da religije imaju ključnu ulogu u definisanju nacionalnih identiteta i neretko imaju pretenzije za dominacijom u političkoj sferi i teokratske ambicije. 